\title{
Pancreatic carcinoma with polyarthritis, fat necrosis, and high serum lipase and trypsin activity
}

\author{
R J van Klaveren, P H M de Mulder, Agnes M T Boerbooms, Christina A van de Kaa, \\ U J G M van Haelst, D J T Wagener, J C M Hafkenscheid
}

\begin{abstract}
A 46 year old white man presented with subcutaneous and intramedullary fat necrosis, destructive polyarthritis, and osteolytic bone lesions, complicating a poorly differentiated adenocarcinoma of the tail of the pancreas with metastases in the liver and omentum. There was a 100-fold increase in serum lipase and trypsin activity. His condition deteriorated rapidly, was characterised by rapid tumour growth, formation of ascites, a $20 \mathrm{~kg}$ weight loss, extensive subcutaneous fat necrosis, and fistula formation in the left calf. Treatment with 5 -fluorouracil $300 \mathrm{mg} / \mathrm{m}^{2}$ on days $1-5$ and doxorubicin $50 \mathrm{mg} / \mathrm{m}^{2}$ and cisplatin $100 \mathrm{mg} / \mathrm{m}^{2}$ on day 1 , every three weeks, was well tolerated and resulted in rapid clinical improvement. After three courses of treatment a partial remission was seen and after seven courses further improvement occurred with a return to normal of serum lipase and trypsin activity. One year after starting chemotherapy the tumour relapsed but responded again to chemotherapy (epirubicin $40 \mathrm{mg} / \mathrm{m}^{2}$ and carboplatin $300 \mathrm{mg} / \mathrm{m}^{2}$ on day 1 , every three weeks).
\end{abstract}

Pancreatic tumours are usually not metabolically active. Since the first description by Berner in $1908^{1}$ only 23 cases have been described. ${ }^{2}$ The syndrome is characterised by fever, polyarthritis, subcutaneous nodular fat necrosis, increased serum lipase activity, and eosinophilia, ${ }^{35}$ and it occurs predominantly in men over 50 years of age. Serum $\alpha$ amylase activity is raised in only about $30 \%$ of cases. ${ }^{3}$ Osteolytic bone lesions may be present, ${ }^{4}$ but ascites is uncommon. ${ }^{5}$ The tumour is considered to be resistant to treatment, ${ }^{3}$ with a fatal course within several weeks or months. ${ }^{6}$

The following report is, to our knowledge, the first documented case of a poorly differentiated pancreatic adenocarcinoma with exceptionally high serum lipase and trypsin activity and a major response to combination chemotherapy.

Values of $\alpha$ amylase, lipase, trypsin, $\alpha_{I}$ antitrypsin, and carboxypeptidase- $B$ on admission

\begin{tabular}{|c|c|c|c|c|c|c|}
\hline & Serum & $\begin{array}{l}\text { Serum } \\
\text { reference } \\
\text { values }\end{array}$ & Urine & $\begin{array}{l}\text { Urine } \\
\text { reference } \\
\text { values }\end{array}$ & Ascites & $\begin{array}{l}\text { Foint } \\
\text { fluid }\end{array}$ \\
\hline $\begin{array}{l}\text { Pancreas amylase }(\mathrm{U} / \mathrm{l}) \\
\text { Salivary amylase }(\mathrm{U} / \mathrm{l}) \\
\text { Total } \alpha \text { amylase }(\mathrm{U} / \mathrm{l}) \\
\text { Lipase }(\mathrm{U} / \mathrm{l}) \\
\text { Trypsin }(\mu \mathrm{g} / \mathrm{l}) \\
\alpha_{1} \text { Antitrypsin }(\mathrm{g} / \mathrm{l}) \\
\text { Carboxypeptidase-B }(\mathrm{U} / \mathrm{l})\end{array}$ & $\begin{array}{c}24-26 \\
11-17 \\
35-43 \\
17600-19840 \\
55000-60500 \\
6810-7320 \\
134-176\end{array}$ & $\begin{array}{c}15-183 \\
15-190 \\
90-330 \\
10-190 \\
140-400 \\
1800-3200 \\
149 \pm 61\end{array}$ & $\begin{array}{l}35 \\
64 \\
99 \\
<1 \\
<1 \\
\text { ND } \\
\text { ND }\end{array}$ & $\begin{array}{l}- \\
- \\
<1500 \\
- \\
1 \cdot 0(+3 \cdot 4)^{\star} \\
- \\
-\end{array}$ & $\begin{array}{l}\text { ND } \\
\text { ND } \\
<33 \\
2975 \\
\text { ND } \\
\text { ND } \\
\text { ND }\end{array}$ & $\begin{array}{r}\text { ND } \\
\text { ND } \\
42 \\
533 \\
\text { ND } \\
\text { ND } \\
\text { ND }\end{array}$ \\
\hline
\end{tabular}

$\mathrm{ND}=$ not done $;-=$ unknown

${ }^{\star}$ Lake-Bakaar G, Summerfield JA. Gut 1978; 19: A960.

\section{Methods}

For the various assays we used the Phadebas IsoAmylase Test (Pharmacia Diagnostics), ${ }^{7}$ the RIA-gnost trypsin radioimmunoassay kit (Behring-Hoechst), ${ }^{8}$ and the Monotest Lipase (Boehringer Mannheim Diagnostics). ${ }^{9}$ Serum carboxypeptidase-B activity was determined by the salmine (protamine) method. ${ }^{10}$ The mean (SD) reference value, determined for 29 healthy volunteers, was 149 (61) U/l. Serum $\alpha_{1}$ antitrypsin activity was measured nephelometrically, using antisera prepared by Dako (Glostrup, Denmark). ${ }^{11}$

\section{Case report}

A 46 year old white man presented in September 1987 with skin lesions resembling erythema nodosum. Within the next three months a severe polyarthritis developed, requiring non-steroidal anti-inflammatory drugs and morphine. Physical examination showed an ill man with normal vital signs, a temperature of $38^{\circ} \mathrm{C}$, and a smooth $10 \times 17 \mathrm{~cm}$ non-tender mass in the left upper abdomen. There was a florid arthritis of the right wrist, the right metatarsophalangeal joints $2-4$, the left ankle, and the right knee. The circumference of the right knee increased when the atrophic upper leg or the tender, swollen inflamed calf were compressed, suggesting an open communication. The left pretibial surface showed several non-tender slightly raised erythematous nodules about $1 \mathrm{~cm}$ in diameter.

Laboratory tests showed the following abnormalities: erythrocyte sedimentation rate $120 \mathrm{~mm}$ in the lst hour (Westergren); haemoglobin $9 \cdot 6$ g/dl, normochromic, normocytic; white blood count $10.2 \times 10^{\%} / 1$ with $5 \%$ eosinophils; alkaline phosphatase $245 \mathrm{U} / \mathrm{l}$ (normal $<120 \mathrm{U} / \mathrm{l}$ ); lactic dehydrogenase $500 \mathrm{U} / 1$ (normal $<300 \mathrm{U} / 1$ ), and gammaglutamyltransferase $84 \mathrm{U} / 1$ (normal $<40 \mathrm{U} / \mathrm{l})$

Aspiration of the right knee and left ankle yielded a yellow-green, creamy, purulent fluid. Many fat globules were shown by Sudan-red stain. Cytological examination showed necrotic material. All cultures were negative. Computed tomography and ultrasonography of the abdomen showed a $18 \times 15 \times 15 \mathrm{~cm}$ mass with hypo- and hyperdense areas, most probably originating from the tail of the pancreas. An exploratory laparotomy showed a large retroperitoneal tumour with several small metastases in the liver and omentum. Conventional histopathology in biopsy specimens from the primary tumour and the metastatic lesions was compatible with a poorly differentiated adenocarcinoma. No signs of pancreatitis were found in the resected specimen. 


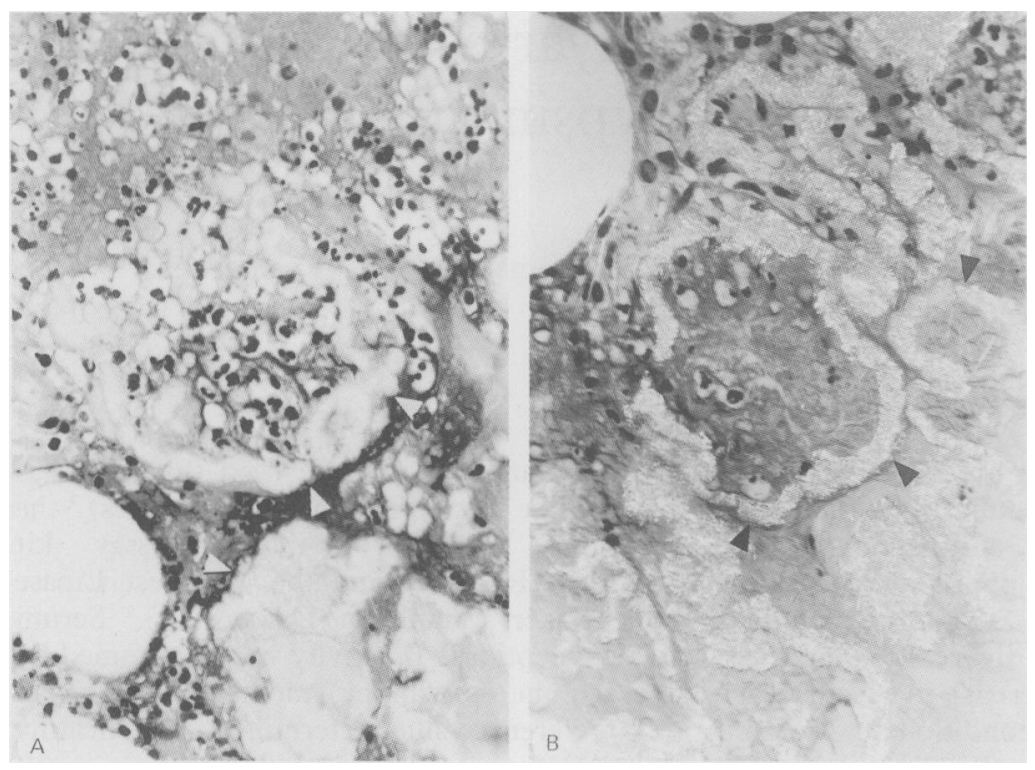

Figure 1: (A) Nodular necrosis is seen in the subcutaneous fat tissue with ghost cells (arrow heads) and a leucocyte infiltrate (Haematoxylin $\mathcal{E}$ eosin. Original magnification $\times 400)$. (B) Birefringent crystals (arrow heads) are shown with polarised light in the periphery of the necrotic fat lobules $(H \mathcal{E} E$. Original magnification $\times 400$ ).
The combination of these findings suggested a functional exocrine pancreatic tumour with fat necrosis. This was confirmed by the serum lipase and trypsin activities, which appeared to be increased 100 -fold. In contrast, serum $\alpha$ amylase and carboxypeptidase- $B$ activities were normal (Table). In unconcentrated urine neither trypsin nor lipase was detected. The serum $\alpha_{1}$ antitrypsin concentration was raised and serum cholesterol and triglyceride concentrations were within normal limits.

Chest $x$ rays were normal. Films of the long bones showed sharply delineated osteolytic lesions.

An arthrotomy of the right knee was performed and $200 \mathrm{ml}$ of creamy debris was evacuated. The synovium was covered with a yellow 'fibrin like' deposit. The osseous parts of the joint showed severe destruction. Histopathology showed a chronic, partly active synovitis. Fat necrosis was seen in the periarticular fatty tissue, in the bone biopsy of the tibia, and in the subcutaneous tissue.

Occasionally, characteristic 'ghost cells' (Fig 1A) with thickened cell walls containing negative birefringent material and von Kossa's negative staining particles were observed (Fig 1B). Extensive immunohistochemical examination was negative. Electron microscopic examination on formalin fixed, paraffin embedded material showed compact cell nests or a tubular pattern with a central lumen lined with apical microvilli. The rough endoplasmic reticulum was remarkably well developed (Fig 2). Neither zymogen nor neuroendocrine granules were detected. Therefore the tumour was classified as a poorly differentiated pancreatic adenocarcinoma.

About four months after the first symptoms the patient deteriorated rapidly. His weight fell by $20 \mathrm{~kg}$, the subcutaneous nodules extended over the whole body, the tumour occupied the whole left part of the abdomen, and ascites appeared. The left calf was drained of $100-200 \mathrm{ml}$ debris daily via a spontaneously formed fistula.

We decided to start treatment with a chemotherapeutic combination of 5-fluorouracil 300

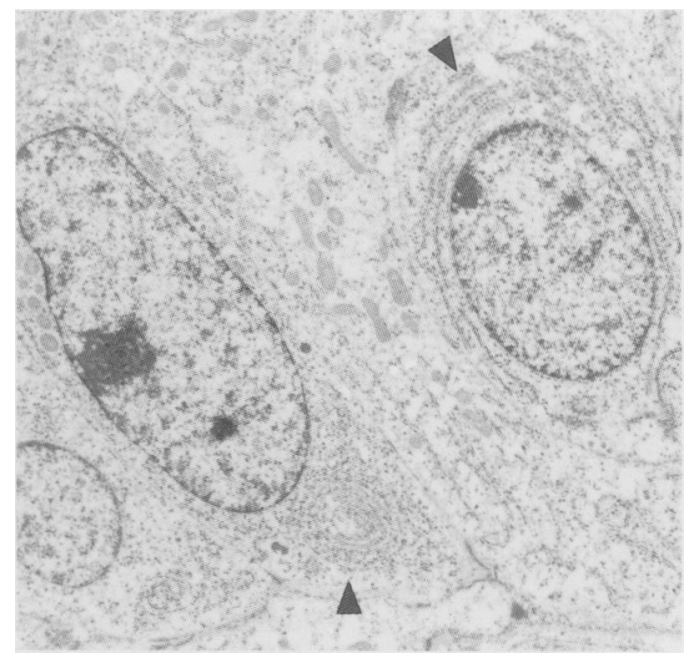

Figure 2: Three tumour cells are partly visible in this electronmicrograph. They are characterised by a well developed, concentrically arranged rough endoplasmic reticulum (arrow heads). Neither zymogen nor endocrine granules were observed (Original magnification $\times 5200$ ).

$\mathrm{mg} / \mathrm{m}^{2}$ intravenous bolus on days 1 to 5 and doxorubicin $50 \mathrm{mg} / \mathrm{m}^{2}$ bolus and cisplatin 100 $\mathrm{mg} / \mathrm{m}^{2}$ in 4 hours intravenously on day 1 every three weeks. After three courses with only minimal early side effects a major clinical response was achieved. Dose reduction to $75 \%$ was needed because of myelosuppression. Evaluation after seven courses showed only a $4 \mathrm{~cm}$ residual tumour mass in the region of the tail of the pancreas, a low grade inflammation of both knees and the left calf, and radiologically unchanged osteolytic bone lesions. Serum lipase and trypsin activity had become normal (Fig 3). Further treatment with combination chemotherapy was impossible because of a progressive polyneuropathy. One year after the start of

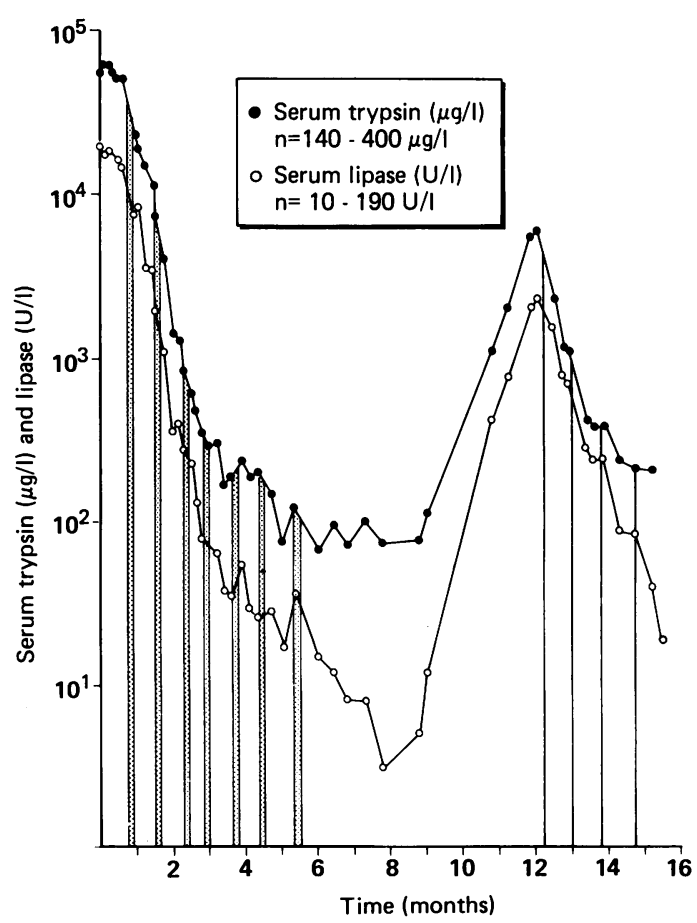

Figure 3: Serum trypsin and lipase activity during chemotherapy. Vertical bars: 5-fluorouracil $300 \mathrm{mg} / \mathrm{m}^{2}$ on days 1-5; doxorubicin $50 \mathrm{mg} / \mathrm{m}^{2}$ and cisplatin $100 \mathrm{mg} / \mathrm{m}^{2}$ on day 1 . Vertical lines: epirubicin $40 \mathrm{mg} / \mathrm{m}^{2}$ and carboplatin 300 $\mathrm{mg} / \mathrm{m}^{2}$ on day 1 . 
chemotherapy and five months after the last course a relapse was discovered by a rapid increase in serum lipase and trypsin activity (Fig 3). A new liver metastasis was detected. After four courses of epirubicin $40 \mathrm{mg} / \mathrm{m}^{2}$ and carboplatin $300 \mathrm{mg} / \mathrm{m}^{2}$, both on day 1 every three weeks, serum lipase and trypsin activity returned to normal (Fig 3), and the liver metastasis almost completely disappeared.

\section{Discussion}

De Graciansky et $a l^{12}$ were the first to show trypsin activity in the discharge of skin nodules in a patient with subcutaneous fat necrosis. Whether trypsin plays an important part in the pathogenesis of fat necrosis remains unclear. Since we measured the sum of trypsin, trypsinogen, and trypsin I bound to antiproteases, the biologically active free trypsin fraction is unknown, and might even be absent, because the antiproteases $\alpha_{1}$ antitrypsin and $\alpha_{2}$ macroglobulin are present in great excess in blood. The $\alpha_{1}$ antitrypsin concentration can even double under various types of stress. ${ }^{13}$ This might account for the absence of trypsin in the urine, and the increase (instead of a decrease) in the serum $\alpha_{1}$ antitrypsin concentration in our patient.

Although we were technically unable to show lipase or trypsin activity in the paraffin embedded tumour tissue, we assume that the tumour produced the enzymes. First of all, trypsin synthesis is attributed exclusively to the pancreas. ${ }^{14}$ is Pancreatitis or pancreatic duct obstruction causes a temporary increase of all exocrine enzymes. ${ }^{14}$ is We measured a persistent 100 -fold increase in serum lipase and trypsin activity, without a rise in $\alpha$ amylase or carboxypeptidase-B. Finally, there was a positive correlation between tumour size and serum lipase and trypsin activity.

The good response to chemotherapy in our patient was remarkable. In the past, corticosteroids, colchicine, and various chemotherapeutic agents were used, but were ineffective. ${ }^{316-18}$ First, we treated our patient according to the phase II study regimen of 5-fluorouracil, doxorubicin, and cisplatin, which is used for inoperable locally advanced pancreatic carcinomas. ${ }^{19}$ After three courses we achieved a partial remission and after seven courses a further regression, approaching a $90 \%$ reduction in total, with normal enzymes and a major palliative result. Five months after the last course of combination chemotherapy the tumour relapsed, but then responded as successfully as the first time to chemotherapy consisting of epirubicin and carboplatin.
Further investigation is needed to establish the value of chemotherapy in the treatment of functional exocrine pancreatic carcinomas. It is clear, however, that the tumour behaves completely differently from the more common nonfunctional pancreatic carcinomas and might therefore be more susceptible to chemotherapy.

We thank Dr D J Ruiter, Department of Pathology, Nijmegen University Hospital, for his helpful suggestions in preparing this manuscript, $M$ Hessels for doing the laboratory determinations, and Dr J van Wijk for referring the patient to our hospital.

1 Berner P. Subkutane Fettgewebsnekrose. Virchows Arch [Pathol Anat] 1908; 193: 510-8.

2 Schreiber D, Probst HJ. Functioning carcinoma of the exocrinic pancreas. Case report and review of the literature. exocrinic pancreas. Case report and review of the

3 Good AE, Schnitzer B, Kawanishi H, Demotropoulos KC Rapp R. Acinar pancreatic tumour with metastatic fat necrosis. Report of a case and review of rheumatic manifestations. Am f Dig Dis 1976; 21: 978-87.

4 Gibson TJ, Schumacher HR, Pascual E, Brighton C. Arthropathy, skin and bone lesions in pancreatic disease. F Reumatol 1975; $2: 7-13$.

5 Potts DE, Mass MF, Iseman MD. Syndrome of pancreatic disease, subcutaneous fat necrosis and polyserositis. Case report and review of literature. Am f Med 1975; 58: 417-23.

$6 \mathrm{Webb} \mathrm{JN}$. Acinar cell neoplasms of the exocrine pancreas. f Clin Pathol 1977; 30: 103-12.

7 O'Donnell M, FitzGerald O, McGeeney KF. Differential serum amylase determination by use of an inhibitor, and design of a routine procedure. Clin Chem 1977; 23: 560-6.

8 Börgström A, Ohlsson K. Radioimmunological determination and characterization of cathodal trypsin-like immunoreactivity in normal human plasma. Scand $\mathcal{F}$ Clin Lab Inves 1976; 36: 809-14.

9 Ziegenhorn J, Neumann U, Knitsch KW, Zwez W. Deter mination of serum lipase. Clin Chem 1979; 25: 1067

10 Riordan JF, Holmquist B. Carboxypeptidase-B. Determination in human serum with salmine (protamine). In: Bergmeyer HU, Bergmeyer J, Grassl M, eds. Methods of meyer HU, Bergers enzymatic analysis. Enzymes 3: peptidases proteinases and the

11 Renckens ALJM, Jansen MJH, Munster PJJ van, Weemaes CRM, Bakkeren JAJM. Serum $\mathrm{K} /$ lambda light chain ratio in normal and diseased children: a nephelometric determinanormal and diseased children: a
tion. Clin Chem 1986; 32: 2147-9.

12 De Graciansky P, Paraf A, Rautureau J, et al. Panniculite nodulaire aigue fébrile récidivante au course d'un cance "acineux" du pancréas. Le problèm de la maladie de Webe Christian. Soc Méd Hốp Paris 1965; 116: 261-82.

13 Mittman C. Antitrypsin. In: Jamicson GA, Greenwalt TJ, eds Progress in clinical and biological research. Vol 5. Trace components of plasma: isolation and clinical significance. New York: Elsevier Scientific, 1976: 261-75.

14 Ventrucci M, Gullo L, Daniele C, et al. Comparative study on serum pancreatic isoamylase, lipase, and trypsin-like immunoreactivity in pancreatic disease. Digestion 1983; 28: immunorea

15 Moss DW, Henderson AR, Kachmar JF. Enzymes. In: Tietz NW. Textbook of clinical chemistry. Philadelphia: Tietz NW. Textbook of clinical

16 Burns WA, Matthews MJ, Hamosh M, Vander Weide G, Blum R, Johnson FB. Lipase secreting acinar cell carcinoma of the pancreas with polyarthropathy. A light and electron microscopic, histochemical, and biochemical study. Cancer 1974; 33: 1002-9.

17 Virshup AM, Sliwinski AJ. Polyarthritis and subcutaneous nodules associated with carcinoma of the pancreas. Arthritis Rheum 1973; 16: 388-92.

18 Tannenbaum H, Anderson LG, Schur PH. Association of polyarthritis, subcutaneous nodules, and pancreatic disease. f Rheumatol 1975; 2: 14-20.

19 Wagener DJTh, Hoogenraad WJ, Kruisselbrink H, et al. Chemotherapy preceding irradiation in locally advanced unresectable carcinoma of the pancreas, a phase III study. In: Wagener DJTh, Blijham GH, Smeets JBE, Wils JA, eds. Progress in clinical and biological research. Vol 201. Primary chemotherapy in cancer medicine. New York: Alan R Liss 1985: 295-300. 